\title{
Culture and Creativity Management: Milan as a Global Capital for Value Creation
}

\author{
Federica Codignola*
}

\begin{abstract}
The topic of creativity and culture in relation to urban value creation and global competitiveness becomes all the more relevant when it allows us to understand the development or the enhancement of cultural and creative industries clusters alongside with the subsequent new geographies shaping cities. In an enclosed area such as a city, the cultural and creative potential is closely related to the scale of innovation and knowledge, let alone to the kind of tourism or cultural occasions that the city provides. This article identifies three specific cultural and creative sectors that are concentrated and coexist in the city of Milan. This article suggests that these sectors may mutually enhance their paths of value creation whilst positively impacting on a unique city's tourist image. In this way, Milan will have the opportunity to become a distinctive global capital of culture and creativity.
\end{abstract}

Keywords: Global Cities; Creative Cities; Creative Economy; Cultural and Creative Management; Creative Industries; Cultural Industries; City Tourism; Tourism Management; Cultural Tourism; Experience Tourism; Fashion; Design; Art; Value Creation

\section{Culture, Creativity, and Urban Progress}

During the last decades in Western societies high added value, along with innovative goods and services, have been fundamental components for economic growth. If we take into account the specific framework of cities, culture and creativity have become renowned instruments for renovating and promoting the development and the image of cities in terms of economic progress and urban regeneration (Bianchini \& Parkinson, 1993). Starting in the late 1970s, in the twenty-first century this trend has highlighted the fundamental role of new actors such as the cultural and creative industries, firms and events, as well as workers (e.g. architects, artists, etc.), who were seen as an innovative class of different subjects and entrepreneurs capable of producing jobs and enhancing the city's economic success (Florida, 2002).

This trend has been followed by a multitude of urban development planning strategies. Many of these have focused on the constitution and promotion of cultural and creative regional or urban areas, districts, or clusters, all of them

\footnotetext{
* Assistant Professor of Management, University of Milan-Bicocca (federica.codignola@ unimib.it)
} 
characterised by an accumulation and convergence of cultural and creative goods, services, and movements. Such accumulation was meant to enhance the city's social level and its economy to create regenerative effects. Viewed as one of the most appropriate strategic tools, the most renowned city branding strategies have been based on cultural and creativity assets (Ponzini \& Nastasi, 2011).

The ongoing international research in this field, however, has criticised these strategies, accusing them of taking advantage and denaturalising culture and the creative processes (Grodach \& Silver, 2013).

This paper explores the possibility of an alternative urban management perspective aimed at merging actors, firms, activities and events pertaining of the three different major cultural and creative industries of the city of Milan (design, art, and fashion). In doing so, this paper argues that it is possible to rethink innovative city tourism strategies that derive from the hybridism of inter-sectoral collaboration between creativity, culture, and industry assets specifically pertaining to the city of Milan.

In fact, with regard to cities' development, the assets through which culture and creativity are often observed and considered as valuable are features that concern both cultural and industrial sets: 'knowledge', 'experience', and 'innovation' (Chapain \& Comunian, 2010; Evans, 2009; Flew \& Cunningham, 2010; O'Connor, 2010; Volo, 2009). It has also been shown how these assets may be conducive to urban progress and global flows of tourism (Castells, 2000; Hall, 2000). Some authors have also highlighted how the increase of business clusters that profit from being positioned in creative cities can generate additional value (Landry, 2000).

This paper explicitly considers three specific cultural and creative sectors that are concentrated and act in the city of Milan. It argues that the sectors of art, design, and fashion can transform this city into a global creative capital. The concentration of these sectors entails the generation of definite cultural and creative areas in which, for instance, there could be high levels of blending between cultural and creative industries and knowledge production (e.g. through the enhancement of entrepreneurial expertise or the development of higher education opportunities). As a result, through representative areas explicitly connected to fashion, design, and art, the city could become a cultural and creative environment that could also qualify as an innovative and attractive global tourist destination.

Globalization has substantially changed the meaning, the role, and the structure of a city. As globalization has brought dramatic and systematic interconnections between individuals, knowledge, resources and goods (Castells, 2000), cities are experiencing a lowering of the traditional limits between the spaces of production and the spaces of consumption. In fact, the city of Milan is no longer perceived as an industrial city from which to escape but, instead, it is more and more perceived as a new attractive tourist destination (Hedrick-Wong \& Choong, 2016). Especially, after Milan Expo 2015, the city has shown to the world its ability to create eventdriven models able to respond to the needs of a global society in search of new experience opportunities linked to knowledge.

$\square$ "The number of tourists visiting Milan last year rose $2.07 \%$ to 5.6 million, according to official figures, showing that Italy's business center was able to reap the beneficial effects of the Expo Milano 2015 world's fair. The feared 'post-Expo' decline hasn't happened and actually the city has been able to capitalize on the international 
visibility created by the event by investing in services, cultural offerings, and attractions" (Mancini, 2017).

The appeal of an urban environment derives from several features that are usually linked to culture, history, progress and consumption. These assets enhance and complete the touristic dimension related to 'experience' (Volo, 2009). A city may provide to the tourist or to the resident a sense of 'multiplicity', which derives from the variety of the city's spaces and activities (e.g. districts, buildings, accommodation structures, museums, events, theatres, shops, parks, restaurants and bars, etc.).

Tourism marketing and tourism management literature have shown that cities are able to fascinate and draw more tourists through the uniqueness of their resources. These may relate, for instance, to natural or cultural resources such as history, traditions, special events, heritage sites, etc. (Cohen, 1997; Dimmock \& Tyce, 2001; Zukin, 1995). In other words, the more a city is capable of distinguishing itself from other competitive cities, the more the reason behind such distinctiveness might represent the core of its consumption system.

The lifestyle associated to such urban destinations can be strategically managed and marketed in order to: 1) attract local and global tourist fluxes; 2) attract local and global investments; 3) allow the city to grow and progress (Bell and Jayne, 2004); 4) create and reinforce the strategic positioning of the destination. Moreover, when such objectives are taken into account, in order to create value to a city and reshape its image, culture and creativity appear of special interest and prove to be particularly appropriate (Hall, 2000).

With the specific framework of cities in mind, we want here to refer the concept of 'culture' to a variety of subjects, organizations, and activities operating in a delimited space and capable of interacting at the same time with the social, cultural, and economic life of such a space. In order to aggregate the concepts of 'culture' and 'creativity', the industry-based approach used by some authors to define the European creative economy appeared to be particularly useful here. Such approach was theorised in The Economy of Culture in Europe Report by KEA (2006) through the 'Culture and Creative Industries Model'. The model itself has been based on Throsby's theory on economics and culture (2001).

Because this paper analyses a cultural sector (art) and two creative industries (fashion and design), both historically associated with the city of Milan, such European-based model is viewed as particularly appropriate. Moreover, this model interprets cultural goods and creative ideas as both deriving from core creative artistic and cultural activities. This is therefore a model that aggregates culture and creativity. The model's representation consists of four ranks of creative economy. The production and the activities of artistic and of cultural organizations are at the centre, whereas the creative industries, which are specifically design-based sectors (e.g. architecture, industrial design, furniture design, interior design, product design, etc.), hold the third rank. This third rank comprises both production-driven and service-driven activities that create goods with functional purposes. At the same time, these goods are strongly based on intellectual property and are endowed with significant aesthetic connotations.

Another model has been created in order to observe the Italian cultural and creative production system (Symbola, 2016). This model, which also aggregates culture and creativity, is divided in two sections. The first section identifies a 
cultural core directly connected to cultural and creative activities. These activities encompass creative industries (e.g. architecture, communication, branding, industrial design, fashion design, etc.), cultural industries (e.g. film, video, TV, radio, videogames, software, music, books, printing, etc.), heritage, visual arts and performing arts. The second section includes creativity-driven activities. Although such activities do not directly belong to the cultural core, they are imbued with and shaped by culture and creativity, although they also contribute to the economic production system (e.g. Made in Italy, food, etc.). Creative industries, in particular, encompass working and organizational outlines based on specific models (e.g. micro-business, collaboration, networking, etc.) which require strategic features such as adaptability, innovation, and constant improvement.

With regard to spatial considerations, it has been observed that creative industries often clusterize in cultural urban capitals and are concentrated in the cities' centres. Such spatial dimensions bring about a gain for the city in terms of economic and social value creation (Castells, 2000). In fact, if individuals physically concentrate close to a sector they are more likely to switch and transfer knowledge, to innovate and create value (Florida, 2004; Porter, 1995).

The whole cultural and creative production system therefore represents an alluring employment opportunity for a young workforce as well as for a creative class in general. In Italy these sectors are characterized by one of the greatest increase rates.

In Italy in 2015 the added value of the 'cultural and creative production system' was worth $€ 89.7$ billion out of a total of $€ 1.468 .9$ (6.1\%). More precisely, the 'cultural and creative production system' was the first segment, followed by 'finance and insurance' (81.4\%), 'healthcare' (78.7\%), 'construction' (71.9\%) and 'mechanics and metallurgy' (34.3\%). In terms of 'employment rate', the 'cultural and creative production system' was worth 1.492 employees out of a total of $24.481(6.1 \%)$.

The internal dynamics of the 'cultural and creative production system' show how in terms of added value and employment rate the creativity-driven activities segment and the design segment (including industrial design, fashion design, graphic design, etc.) are the best performers $(+5.4 \%$ and $+10.8 \%)$.

Between 2011 and 2015 design firms in Italy have increased by $10.9 \%$. Italian design firms represent, as regards turnover, the second country in Europe (18.3\% out of the total UE value), second only to the United Kingdom. Concerning the professional design profiles, in 2015 the industry demand saw an increase by $53.8 \%(+17.7 \%$ of the average) compared with 2014.

As for the Italian regional capitals' role in the 'cultural and creative production system' whole economic worth, the city of Milan represents $10.4 \%$ ( $€ 14.5$ billion out of $€ 139.5$ billion) in terms of added value and $10.5 \%$ ( $€ 187.4$ billion out of $€ 1.783 .7$ billion) in terms of 
employment rate. Source: Symbola, Rapporto 2016 Io Sono Cultura (2016).

It is therefore not surprising that the sector today fulfils a main role in urban progress planning and/or renovation strategies, which, of course, include and impact the tourism local economy. In Milan, but also in other global tourism capitals, developing and promoting creative areas is an increasingly popular policy (Bell and Jayne, 2004) which, in turn, can produce added-value. Urban progress is not only a matter of tangible development, but it also requires intangible assets linked to creativity (Florida, 2005).

$\square$ For example, by observing the spillover and multiplier effects of the 'cultural and creative production system' in 2015 in Italy, it has been shown how for any value added euro generated by the system, another 1.8 euro is produced in the remaining part of the economy. Therefore, if we consider the sector's added value of $€ 89.7$ billion, the whole industry is worth $€ 249.8$ billion, which corresponds to $17 \%$ of the whole national added value.

$\square$ For instance, taking into account tourism activation and contribution, in Italy the 'cultural and creative production system' in 2015 has impacted for $€ 29.1$ billion, representing $37.5 \%$ of the whole tourism expenditure (in 2011 it was 33.6\%). Source: Symbola, Rapporto 2016 Io Sono Cultura (2016).

\section{Culture and Creativity as Driving Forces for Global City Tourism}

In a delimited territory the presence of a valuable historical heritage alongside with plentiful creative and cultural activities can only implement a global city's tourism demand. In fact, it has been demonstrated that culture is the main reason for global tourism (World Economic Forum, 2015).

As globalisation has brought a noticeable increase of the tourism industry competition, the management of such business in different countries has become more difficult. Such a complex background compels tourism managers and marketers to acquire new skills and to develop new strategies (Moutinho, 2000; Heath, 2001). They have to deal with several important changes such as the ones concerning the expansion of communication and information technologies, new consumer behaviours, and some significant socio-cultural alterations.

Last, not least are a tourists' growing sensibility for local values (linked to tradition, culture, art, etc.) and a parallel desire to live tourism through 'experiences'.

Tourism has become a fundamental element of the social life, the geography, and the economy of numerous global capitals and is perfectly situated to seize the opportunities offered by urbanization. Nevertheless, several challenges emerge, showing the urgency to handle successfully the increase of tourism in cities and capitals around the world. 
Among current management strategies (e.g. relating to spatial regeneration, sustainable growth, etc.), local culture may be of particular importance. In cities, local culture and local creativity tend to develop in and through clusters. In this sense, cultural and creativity management dealing with global cities needs to build up strategies capable of connecting private and public actors from different sectors (Sweeting, 2002). Such practices are central to the current idea of city tourism advancement. Aside from its primary goal of economic production, tourism must function as a device for cultural conservation and social solidity.

An innovative managerial city tourism approach must recognize the key functions of culture and creativity as driving forces for economic and social progress in cities. Such approach must also situate the sector as a main concern in city planning. On the one hand, many cities have become global tourism destinations because of their cultural resources, either linked to tradition like 'Flamenco' in Seville or to a specific icon like the Guggenheim in Bilbao. In fact, a city may concomitantly offer a wide range of diverse cultural expressions through its events, icons, lifestyle, food, historic buildings, tradition, history, arts and crafts, etc. (Richards, 2001). On the other hand, culture and creativity help delineate a sense of place for local inhabitants (Kay \& Watt, 2000; Pine \& Gilmore, 1999).

More precisely, local culture and local creativity can improve city tourism in many different ways, either formally or informally. Take for one the extremely successful case of the Venice architecture and art biennials. Both encompass the renovation of the city's image; the definition of a collaboration project between private and public players; the creation of diverse tourists and locals' connections; the production of innovative activities and practices through cultural and creative expressions; the management of inventive differentiation strategies, etc.

By taking into account similar policies, a city can certainly benefit from a stronger position in a highly competitive global city tourism marketplace. Such strong competition has intensified at many levels including customers' demand for 'experiences' but also for an improved quality tourism at lower prices (D'Aveni \& Gunther, 1994). In this sense, culture and creativity represent a perfect twin strategy capable of fulfilling these requirements.

City tourism managers can merge several features of experiences in order to generate innovative cultural and creative experiences. This may create shifts in the way in which cities and cities' areas are perceived, and lived, by both the visitors and the local community. By choosing a distinctive cultural and creative management strategy the challenge for the city would be to locate one or more contexts through which to generate and increase value creation. This requires the development of collaborative activities between attainable creative and cultural resources and the relative needs of inhabitants and tourists.

As already mentioned, such paradigm draws a global 'creative class' (Florida, 2004) which can physically relocate to the city (e.g. because this offers specialized and globally recognized creative or cultural higher education institutions) or simply visit it and consume it on a regular basis. This new appealing and vivid atmosphere can act as a magnet for both tourists and locals. However, literature has shown that, in terms of city tourism development, an endogenous creative class alongside with endogenous models of culture and creativity is more successful with tourists and residents, but also with regard to other flows of ideas and actors (Richards \& Raymond, 2000). 


\section{Place-driven Resources and Local Knowledge}

As already mentioned, some of the traditional boundaries in the cultural and the creative industries have become more fluid. As an example, some authors note an evident shift from tangible trades to an image industry (McRobbie, 1998). Because of that, firms' competitive advantage derives essentially from the production and the management of knowledge (e.g. fashion and design knowledge) (Power \& Hauge, 2008). For instance, global fashion capitals participate as focal hubs in strategic global networks (Sassen, 1991) while hosting at the same time firms' headquarters of the main global fashion and luxury industry companies. This fact, alongside with the presence of specialized industrial networks, inevitably creates cities' clusters endowed with a unique creative atmosphere (Breward et al., 2004).

At the same time, such conditions develop employment opportunities, specialized higher-education settings, specialized services, knowledge production and knowledge exchange circumstances, product innovation, collaboration dynamics between firms and sectors and finally a predisposition to internationalisation (Breward \& Gilbert, 2006; Hauge, 2007; Rantisi, 2004; Weller, 2007; Zukin, 1991). In other words, cities characterized by these features achieve a more efficacious circulation and consequently a more effective commercialization of a specialized knowledge, such as the knowledge linked to fashion or design.

For sectors such as art (e.g. the art market with its players and organizations), fashion, and design, the product's added value essentially depends on intangible assets. Therefore reputation-driven, image-driven, and competitive advantagedriven strategies become fundamental (Power and Scott, 2004). As art, design, and fashion goods are inherently based on symbolic, aesthetic, and cultural features, interactions between such sectors become of strategic relevance for firms and organizations but also for the city that hosts these interactions.

In this sense, for both tourism city managers and firm managers, location-based associations may be extremely relevant. They can help systematize and commercialize the cultural and creative knowledge stemming from these cultural and creative sectors as they are incorporated in the city. Some authors, for instance, have argued that in the consumers' evaluation process, products are often inseparable from their place-based associations (Molotoch, 2003). Therefore organizations, firms, and brands pertaining to art, design, and fashion and acting in a particular city must exploit that particular city's sensation and transform it into a strategic device.

Constructive associations linking a recognizable city and a successful products/firms/organizations' image (e.g. a Milanese art gallery, event, fashion or design firm, etc.) might then generate added value for the city by allowing the city to succeed against global competition. At the same time, these associations might positively impact on the firm or on the organization's image by signalling how these are geographically located. Globalization entails multiple benefits. First of all, art, design, and fashion are strictly connected to local cultural and industrial origins, know-how, knowledge, and typical backgrounds. Yet, these sectors are all embedded in a global system, act in a global market, and deal with global demands (Codignola, 2015). In sum, from the one hand cultural and creative-oriented sectors might opt to locate themselves in global cities by taking advantage of their ability to be global hubs through which all the topical diverse resources (e.g. individuals, ideas, technologies, mobility opportunities, velocity, etc.) globally circulate or 
concentrate (Breward \& Gilbert, 2006). On the other hand, by attracting such resources and consequently by continuing to draw creative and cultural-driven firms and organisation, the city will continue to be perceived as a global capital of creative knowledge. This condition can both enhance a city's attractive capacity for globalized tourisms and boost its image for the local inhabitants.

In other words, by exploiting this model, the city's economy alongside with its cultural and creative planning strategies must take advantage of the constructive effect that emerges from the association with the three most representative creative and cultural sectors such as art, design, and fashion. These sectors with their markets, other than being globalized and concurrently embedded with local knowhow, history, culture, etc., also symbolize some of the most trendy, successful, and healthy industries of the world.

\section{Art, Design, and Fashion between Local Features and Global Circuits}

Art, design, and fashion are very different sectors. However, they share the symbolic and idiosyncratic character of their goods. They also act through comparable culture and creativity-driven consumer market segments. Finally, they all form crosswise value creation systems where they operate with similar patterns. For example, all these sectors follow a precise annual rituality built around repeated central events that take place in the same global capitals (e.g. Art Basel, Frieze London, The Venice Art Biennial, etc. for art; the Milan or Paris Fashion Week for fashion; the Design Week in Milan or Maison et Objet in Paris, etc. for design; and so on). All these events attract significant fluxes of global visitors. Moreover, such art, design, and fashion events all create a collateral system of satellite events disseminated all around the city. In general, the main events take place in various geographical areas and involve different local players. At the same time, these events become increasingly glamorous and popular, so that they too capture the medias' attention and coverage.

Another common feature is the physical formats that art, design, and fashion share in relation to both the creative and the commercial spaces (e.g. ateliers and studios, private galleries and showrooms, etc.). Also, these sectors are all connected to a specific star system formed either by famous fashion or product designers or by popular artists, curators, dealers, collectors, etc. Moreover, the three sectors share a similar pattern with regard to the creation and the exploitation of a reference system formed by specific cultural or historical movements and fashions (e.g. Arte Povera in art, the Sixties in fashion, Organic Design in design, etc.).

Finally, and most significantly, these sectors share a primary connection with locality which becomes a fundamental value-generator. In sum, the three sectors are closely connected through and by global circuits and global fluxes of people, events, etc. Yet they are also dramatically embedded in their local precious components. These refer to specific historical, cultural, or industrial original reference systems from where every sector has initiated or from which they have been deeply influenced (e.g. Modern Art or the haute couture in Paris, the Radical Design movement in Milan, the Monza and Brianza design district in Lombardy, etc.). 


\section{Managing Cross-Sectoral Connections and Value Creation}

If they are located in the same area, such as the same city, these local features and global circuits may strategically cross and produce value. Today, creative crosssectoral relationships are of great economic significance. In fact, they help comprehend how these different activities and business can generate profitable associations between their goods, companies, and organizations aimed at generating and managing value (Scott, 2000).

As mentioned, the three sectors of art, design, and fashion are homogenously part of the cultural and creative industries. Moreover, as they share peculiar features they can easily be comparable.

Some networks researchers have observed the relationships through which culture and economy efficaciously interact and generate value (Amin \& Trift, 2004). Other authors have highlighted the weight of valuable cross-sectoral relationships specifically focusing on cultural and creative goods (Leslie \& Reimer, 2003). In sum, as art, design, and fashion are shaped by different but complementary flows of value, these flows can be shared in order to enhance reciprocal value.

During the last decade, a homogenization of the creative, productive, and commercial paths through which art, design, and fashion operate has become increasingly evident. For instance, with regard to the art sector and its creative and productive process, a growing number of successful contemporary artists have acquired the status of a firm. In fact, a conspicuous number of employees physically bring to life the artworks, powerful marketing strategies are in place, etc. Moreover, alike fashion and design, the art sector uses the same trade platforms model (e.g. the fairs). In sum, these intersections are such that the three sectors show that many collaborative strategies are already in place. In the creative processes as well in the commercial strategies collaborative methods and practices between artists, fashion brands, and product designers or architects are increasingly evident. For instance, art shares some of the major traits of luxury fashion goods and of high-end design goods. These are high quality and price, rarity, extraordinariness, aesthetics and symbolism, etc.

For this reason, fashion is the sector where to identify such intersectoral collaborative approach is most easily identifiable. Fashion's collaborations and associations with art, design, or architecture, will attract the attention of the media and of the public and revitalize the brand's creativity. In doing so, the brand will for example become related with the celebrities of the contemporary art world, providing evidence of its aesthetic sensibility (Chevalier \& Mazzavolo, 2011).

Luxury fashion firms are particularly at ease with creativity-driven collaborative approaches. These can take the shape of a range of strategies that envisage cooperations with architects, product designers, contemporary artists, corporate art collectors, patrons, supporters of art exhibitions, charity-event organizers, etc. (e.g the realization of iconic and representative art spaces such as Prada Foundation in Milan; the Louis Vuitton Foundation in Paris; the Pinault Foundation in Palazzo Grassi and Punta della Dogana in 
Venice or the future one in Paris; fashion collaborations with contemporary artists such as Daniel Buren, Takashi Murakami, Olafur Eliasson, Richard Prince, Yayoi Kusama or with architects and product designers; etc.). Nevertheless, some commercial locations too (not only cultural) such as the flagship stores and the temporary stores are strictly linked with design, art, and creativity and often become a symbol of a specific city (e.g. some luxury fashion stores or buildings are widely recognized as being very particular; in that way, for some, they contribute to characterize a city becoming at the same time its symbols).

Theory and the successful practical examples provided so far confirm that these three sectors can profitably blend whilst efficaciously enhancing value creation and competitive advantage. This process is made possible by the achievement and enforcement of their mutual specialized creative knowledge. Given the crucial importance of 'image-driven' strategies in today's markets, competitive advantage has to be established through the creation and the managing of specific cultural and creativity-driven knowledge. A unique knowledge contains in fact a variety of unique marketable output that can be exploited and converted in flows of value.

\section{Managing Milan's Valuable Cultural and Creative Assets through Art, Design and Fashion}

Any observation of localized systems implies an interpretation of the links connecting local clusters. This interpretation can be efficaciously performed through the 'relational paradigm' (Bathelt at al., 2004; Dicken et al., 2001; Yeung, 2005). Such model emphasizes the relationships among individuals, goods, and production chains' networks. As a consequence, the city of Milan, with its recognized cultural and creative sectors of art, design, and fashion, can indeed be identified as a specific area formed by local, global, and networked cultural and creative flows of value.

The city of Milan is internationally recognized for its creative industries, especially for design and fashion (d'Ovidio, 2015; Knox, 2014; Perulli, 2015). At least two studies have demonstrated that Milan can claim the greatest number of Italian creative actors. They have also shown that one third of Italian professionals work in the cultural or in the creative sector (Bonomi, 2012; Mingione et al., 2007). Furthermore, with regard to the art sector, the city of Milan has always been internationally recognized for its unique intellectual and artistic scene, especially from the late 1800s well into the 1900s. In fact, since the 1930s Milan's private art galleries have provided an essential common platform for the most important European art vanguards while allowing the development of the most significant Italian artistic movements of the $20^{\text {th }}$ century (Codignola, 2014). Yet today the Milanese art scene is widely criticized for what is believed a scarcity of private and public investments (D’Ovidio, 2016; Mingione et al., 2010).

With regard to recent cultural planning and cultural policies, the city of Milan has already pursued managerial and marketing models based on city branding strategies. These strategies are mostly focused on branded and highly promoted 
annual mass events aimed at bringing significant fluxes of visitors and of money into the city.

For example, the Milano Design Week; the Milano Fashion Week; the Milano Bookcity; the Milano Piano City; the Milano Food Week; the Milano Arch Week; the Milano Film Festival; the Milano Photo Week; MIA Photo Fair Milano; Miart Fair Milano; the Vogue's Fashion Night Out Milano etc.

The limits of such strategies are perhaps to be seen in two elements. First of all, there is a risk of 'confusion' for locals and tourists deriving from too many events that are also too similar in format and label. This could certainly create 'dispersion' phenomena in the fruition process. The second element, is the disconnection of these events: too close for their creative and cultural nature, yet too specialised, therefore disjointed. Moreover, all these mass events seems unable to really increase the value of the local resources. In fact, the constant recurrence of the Milan brand name in the events' labels does not correspond to a true involvement of the authentic local resources that should instead be the real protagonists. This is evident when one observes the effective events' contents, local knowledge, knowhow, culture, etc. that are always mixed with non-local elements. An author believes that the lack of institutional funds for the cultural and artistic sectors may compel the creative class (e.g. especially the artists) to react merely to mass market paradigms while inhibiting the authentic creative force (Agosti, 2010).

In order to bring about a model alternative to such disaggregate creative city branding model, a cross-sectoral framework involving fashion, art, and design is of particular interest here. The three sectors bring together in the city of Milan a multiple range of significances and specialisations whose common denominator is creativity, a multidimensional and culturally permeated form of knowledge that bridges cultural and creative production with consumption (e.g. fashion designers, product designers, artists; specialised fashion, design, or art media; events' organisers; fashion or design retailers and wholesalers, art gallerists or art dealers; clothing or product design manufacturers, textile or industrial designers, art frames manufacturers or art exhibitions' designers; other specialised fashion, design, and art intermediaries, etc.).

The shared features and aesthetic nature of these three sectors generate crosssectoral networks of potential collaboration that may blend a variety of goods, services, actors and significances. However, in order to exploit such intersections and transform the city of Milan into a global representative cultural and creative capital, specific managerial and marketing strategies have to be intelligently handled. For instance, instead of conceiving disaggregated events in too many different areas of the city, a new model would select few specific physical spaces while labelling them as the city's institutionalized zones jointly devoted to art, design, and fashion. This would improve the perceived value of both the city's unique art, fashion, and design assets and their participants.

These few selected urban areas may then become strategic spaces where the relations between such cross-sectoral public can be organised and exploited. For instance, the creation of cross-sectoral special events in recognizable areas would 
allow to establish and transmit an aura of trendiness and inimitable Milanese lifestyle based on design, art, and fashion.

In order to exploit and enforce such unique flows of value, an effective city tourism managerial strategy should consider marketing communication tools as essential. This would help give to the city of Milan a recognizable role as global creative and cultural capital (e.g. the leading global capital for art, fashion, and design).

For instance, city tourism managers should brand these collaborative events involving design, art, and fashion precisely through their qualities of global reach and creative success. This would generate additional benefits to the city's image and reputation. At the same time, a Milanese background that draws upon such tangible and intangible peculiar cultural and creative resources, would obviously facilitate the task.

As above mentioned, the city of Milan is already perceived as a beacon for modern and contemporary art and as a global capital in design and fashion. This is evident from the number of events, fairs, and specialized higher education organizations located in the city and accredited throughout the world. Milan truly represents a key node for design, art, and fashion education, production, distribution, $R \& D$, and communication.

$\square$ For instance, the city hosts some of the most globally-recognized higher education programs specializing in art, design, and fashion: Politecnico University, IED Istituto Europeo di Design, Istituto Marangoni, Bocconi University, Naba Academy, Brera Academy, IULM University, etc. These specialized higher education organizations alongside with the above mentioned events, fairs, etc., all attract global fluxes of international students, professionals, and visitors.

As for local cultural and creative roots, Milan has developed many diverse traditions, including modern and contemporary art movements, luxury goods segments, product design and architectural trends, high-end fashion styles and so on. These traditions were rooted in the city's long-standing role as the Italian financial and industrial core. After deindustrialization, a solid and well-performing background of interconnected creative and cultural industries has emerged. Among their markets, design, fashion, and modern and contemporary art are those most closely associated with the region of Lombardy and Milan. There is a reason for that -- the city represents a relevant manufacturing cluster for these sectors; at the same time, it is a centre for the creation and dissemination of unique knowledge.

Milan's reputation also depends on the symbolic constructs and narratives embedded in design and fashion. These constructs create an aura of trendiness and lifestyle that makes Milan inherently linked with some of the values associated to both (aesthetics, image, trendsetting, exclusiveness, craftsmanship, etc). Because art with its market - of late an extremely trendy sector -- is intrinsically related to some of these features, it can surely add to Milan's cultural and creativity global reputation.

Therefore, in order to sustain the high quality outputs needed to uphold high quality creative and cultural tourism, the city of Milan needs to brand itself as cultural and creative through its unique features. However, instead of choosing 
'hard branding' and dispersive mass events' strategies, Milan should begin to plan a communication strategy focused on the promotion of its few selected design, art, and fashion dedicated spaces. If similar cross-sectoral experiences are marketed by fewer specialized events, in fewer specific areas, and under a unique brand (e.g. 'Milanocreativa' or 'Milanolifestyle', and so on), demand would increase and would be better met.

Through these city brands the Milanese cultural and creative economy could thus provide an overall framework for inhabitants to imagine themselves. A construction of a brand story of Milan as a cultural and creative hub focused on design, art, and fashion would narrate Milan as a city that has always mixed the best of history and innovation, the traditional and the contemporary. This meaning must be efficiently communicated to not only tourists but also to its inhabitants. In other words, a Milanese brand story should become a framework to recognize and present Milan's uniqueness, in order to both attract international and local visitors, and highlight Milan in the global cultural and creative economy.

These three sectors share many traits and can successfully associate and collaborate. In fact, as for cultural and creative industries, art, fashion, and design are increasingly subject to inter-sectoral fertilization and blending, with blending being viewed as a structural process featured by inter-sectoral making of products and services and by high degrees of inter-sectoral networking. More generally, if we take into account markets and consumers, we can observe that, where markets were formerly disconnected and based on different consumer demands and desires, today's consumers are demanding comparable goods at any time, wherever, and through any distribution device. In the meantime, they are also switching from representing passive content consumers to prosumers.

For all these reasons, in relation to a content-driven perspective, a concrete Milanese tourism differentiation strategy should focus on the creation and the promotion of the above mentioned selected areas that include and endorse the city's major design, fashion, and art firms, organizations, and players, while facilitating cross-sectoral collaboration (e.g. through specific labelled events). Under a unique Milanese branding strategy, coordinated or co-organized events among the three sectors should develop a coherent and articulate programme of various creativityand culture-driven activities, dealing directly with city-related design, art, and fashion individuals or organizations (a fundamental part of the Milanese creative class). This agenda should also include strategies aimed at attracting international talents, for example by stimulating design, fashion, and art firms and organizations to host international artists or young talents through residencies' programmes.

From a more practical perspective, social networks marketing strategies alongside with multi-device tasks and content distribution, and a focus on the strategic role of user generated content would be generally functional and valuable. In fact, if adequately promoted, such a planned cultural and creative strategy conveying design, art, and fashion with their knowledge and resources would certainly add value to experiential tourism. In this sense, this strategy would also impact on visitors' expenditures. At the same time, it would enhance creativity- and innovation-driven sectors' opportunities while impacting on the locals.

Through a well-defined creative and cultural area (or areas) specifically referred to design, art, and fashion, Milan would certainly help to create an environment in which related knowledge and creativity can spread out and be exploited. In turn, this strategy would enhance urban progress while increasing differentiation in the 
tourist offer in the city. Obviously, the promotion of these cultural and creative zones requires an immediate message that can be easily and successfully communicated to heterogeneous publics, encompassing global visitors, some of whom might be not entirely aware of the historical, cultural, industrial and social Milanese context. Thanks to thematic high quality special events, learning opportunities, etc., tourists would satisfy their experiential aspirations and probably prolong their stay in the city.

In sum, a similar strategy would help establish Milan as a key global capital for value creation. More specifically, whereas various 'soft' inputs may be achieved (e.g. an increase the city's creative profile and internal investments), this strategy could create an exciting and commercially flourishing economic cluster that would be globally recognized. This condition would produce benefits to both the three sectors and the city's local communities.

When a global capital selects culture and creativity as its key driver of value creation, results can be seen in terms of its attractiveness and global competitiveness. Such a strategic choice would in fact bring further differentiation, diversification, and an innovative tourist offer. 'Authenticity' often represents the asset of a unique tourism experience. Milan, then, through a specific representative art, design, and fashion-driven area can generate a locally-embedded site for setting flows of creative and cultural values. In consuming these values the tourist will become implicated in cultural and creative processes whilst building its own authentic experience.

In conclusion, creativity and culture can be a significant label for marketing a destination. At the same time, the original idea of creativity and culture derives from a natural process fed by diverse cultural flows and relationships. Therefore an innovative creative improvement lies more in the achievement of collaborative advantage rather than competitive advantage. In sum, the development of synergies between collaborating players and organizations from design, fashion, and art appears to be a successful strategy. This would move the city of Milan into a new complex of resource implications, organizational systems, and relationships but it would also increase management challenges and enhance the complexity of a culture and creativity oriented urban planning.

Nevertheless, future researches should enrich the debate over the role of marketing in cultural and creative cities, for instance by investigating the general effectiveness of a cultural and creative city brand and by measuring the impact of culture and creativity in renewing a city's image. At the same time, the complex relationship between diverse cultural and creative sectors such as art, design, and fashion alongside with their connections with cities' tourism dynamics and cities' areas underlines the urge for further examination and multidisciplinary approaches.

\section{Bibliography}

Agosti, G. (2010). Le Rovine di Milano, Feltrinelli Editore, Milan.

Amin, A. \& Thrift, N. (2004). Introduction, in A. Amin \& N. Thrift (eds.), The Blackwell Cultural Economy Reader, Blackwell, Oxford.

Bathelt, H., Malmberg, A. \& Maskell, P. (2004). Clusters and Knowledge: Local Buzz, Global Pipelines and the Process of Knowledge Creation, Progress in Human Geography, 28, 31-56. 
Bell, D. \& Jayne, M. (2004). City of Quarters: Urban Villages in the Contemporary City, Ashgate, Aldershot.

Bianchini, F., \& Parkinson, M. (1993). Cultural Policy and Urban Regeneration. The West

European Experience, Manchester University Press, Manchester.

Bonomi, A. (2012). Milano: le Tre Città che Stanno in Una, Mondadori, Milan.

Breward, C., Ehrman, E. \& Ewans, C. (2004). The London Look: Fashion from Street to Catwalk, Museum of London, London.

Breward, C. \& Gilbert, D. (eds.). (2006). Fashion's World Cities, Berg, New York.

Brondoni, S. M. (2015). Global Networks, Outside-In Capabilities and Smart Innovation, Symphonya. Emerging Issues in Management (symphonya.unimib.it), (1), 6 - 21.

http://dx.doi.org/10.4468/2015.1.02brondoni

Brondoni, S. M. (2014). Global Capitalism and Sustainable Growth. From Global Products to Network Globalisation, Symphonya. Emerging Issues in Management (symphonya.unimib.it), (1), $10-31$.

http://dx.doi.org/10.4468/2014.1.02brondoni

Brondoni, S. M. (2008). Market-Driven Management, Competitive Space and Global Networks, Symphonya. Emerging Issues in Management (symphonya.unimib.it), (1), 14-27.

http://dx.doi.org/10.4468/2008.1.02brondoni

Bulhalis, D. \& Cooper, C. (1998). Competition or Co-Operation? Small and Medium Sized Tourism Enterprises at the Destination, in Embracing and Managing Change in Tourism: International Case Studies, Laws, E., Faulkner, B. \& Moscardo, G. (eds.), 324-346, Routledge, London.

Castells, M. (2000). The Rise of the Network Society, Blackwell (2nd edition), Oxford.

Chevalier, M., \& Mazzalovo, G. (2011). Management et Marketing du Luxe (2nd ed.), Collection Marketing Sectoriel, Dunod, Paris.

Codignola, F. (2014). Contemporary Art and Urban Regeneration in the City of Milan, Tafter Journal, 71 .

Codignola, F. (2015). The Globalization of the Art Market: A Cross-Cultural Perspective Where Local Features Meet Global Circuits, in J. M. Alcántara-Pilar, S. del Barrio-García, E. CrespoAlmedros \& L. Porcu, (eds.), Analyzing the Cultural Diversity of Consumers in the Global Marketplace, 82-100, IGI Global, Hershey.

http://dx.doi.org/10.4018/978-1-4666-8262-7.ch005

Cohen, S. (1997). More than the Beatles: Popular Music, Tourism and Urban Regeneration, in S. Abram, S. Waldren \& D. Macleod (eds.), Tourists and Tourism: Identifying with People and Places, Berg, Oxford.

Coles, T., Hall, C. M. (eds.) (2008). Tourism and International Business, Routledge, London.

Cooper, C., \& Hall, C. M. (2013). Contemporary Tourism: an International Approach, 2nd ed. Goodfellow, Oxford.

D’Aveni, R. A., Gunther, R. (1994). Hypercompetition: Managing the Dynamics of Strategic Manoeuvring, The Free Press, New York.

D’Ovidio, M. (2015). The Field of Fashion Production in Milan: a Theoretical Discussion and an Empirical Investigation, City, Culture and Society, 6(2).

http://dx.doi.org/10.1016/j.ccs.2015.02.002

D’Ovidio, M. (2016). The Creative City does Not Exist. Critical Essays on the Creative and Cultural Economy of Cities, Ledizioni, Milan.

Dicken, P., Kelly, P., Olds, K. \& Yeung, H. W. C. (2001). Chains and Networks, Territories and Scales, Global Networks, 1(2).

Dimmock, K. \& Tyce, M. (2001). Festivals and Events: Celebrating Special Interest Tourism, in N. Douglas, N. Douglas \& R. Derrett (eds.) Special Interest Tourism, Wiley, Milton, Queensland.

Florida, R. L. (2002). The Rise of the Creative Class: And How It's Transforming Work, Leisure, Community and Everyday Life, Basic Books, New York.

Florida, R. L. \& Tinagli, I. (2004). Europe in the Creative Age, DEMOS/Carnegie Mellon University, London. 
Florida, R. L. (2005). Flight of the Creative Class: The New Global Competition Talent, Harper Collins, New York.

Gnecchi, F. (2009). Market-Driven Management, Market Space and Value Proposition, Symphonya. Emerging Issues in Management (symphonya.unimib.it), (2), 33-45.

http://dx.doi.org/10.4468/2009.2.04gnecchi

Grant, R. M. (2000). Shifts in the World Economy: The Driver of Knowledge Management, in C. Despres, \& D. Chauvel (eds.), Knowledge Horizons: The Present and the Promise of Knowledge Management, Butterworth-Heinemann, Oxford.

Grodach, C., \& Silver, D. (2013). The Politics of Urban Cultural Policy: Global Perspectives, Routledge, New York.

Hall, P. (2000). Creative Cities and Economic Development, Urban Studies, 37.

Hauge, A. (2007). Dedicated Followers of Fashion: An Economic Geographic Analysis of the Swedish Fashion Industry, Uppsala University, Uppsala.

Hedrick-Wong, Y. \& Choong, D. (2016). Global Destination Cities Index by Mastercard, Retrieved in: $\quad$ https://newsroom.mastercard.com/wp-content/uploads/2016/09/FINAL-Global-DestinationCities-Index-Report.pdf

Heath, E. (2000). Key Trends in Destination Marketing: Lessons from Global 'Best Practice' Destinations, in Ruddy, J. \& Flanagan, S. (eds.), Tourism Destinations: Gaining the Competitive Edge, Tourism Research Centre, Dublin Institute of Technology, Dublin.

Kay, A. \& Watt, G. (2000). The Role of the Arts in Regeneration, Scottish Executive Central Research Unit, Edinburgh Research Findings, 96.

KEA European Affairs. (2006). The Economy of Culture in Europe, European Commission, Director-General for Education \& Culture, Brussels.

Keller, P. (1996). Globalisation of Tourism, AIEST, St. Gallen.

Knox, P. L. (2014). Atlas of Cities, Princeton University Press, Princeton.

Landry, C. (2000). The Creative City. A Toolkit for Urban Innovators, Earthscan, London.

Leslie, D. \& Reimer, S. (2003). Fashioning Furniture: Restructuring the Furniture Commodity Chain., Area, 35, 427-437. Retrieved from http://www.jstor.org/stable/20004347

Mancini, G. (2017). Milan Riding Strong Wave of Post-Expo Tourism, Il Sole24Ore. Retrieved in http://www.italy24.ilsole24ore.com/art/business-and-economy/2017-01-24/milan-riding-wave-ofpost-expo-tourism-131501.php?uuid=AEWtMyG

McRobbie, A. (1998). British Fashion Design: Rag Trade or Image Industry? Routledge, London.

Mingione, E., Zajczyk, F., Dell'Agnese, E., Mugnano, S., D’Ovidio, M., Sedini, C., et al. (2007).

Milan City-Region: Is it Still Competitive and Charming? Pathways to Creative and Knowledge-

Based Regions, AMIDSt, University of Amsterdam, Amsterdam.

Mingione, E., Zajczyk, F., Dell'Agnese, E., Mugnano, S., D’Ovidio, M., Sedini, C., et al. (2010).

Policies and Strategies in the Metropolitan Region of Milan. How to Enhance the City's

Competitiveness, AMIDSt, University of Amsterdam, Amsterdam.

Molotch, H. (2003). Where Stuff Comes From: How Toasters, Toilets, Cars, Computers and Many Other Things Come to Be as They Are, Routledge, London.

Moutinho, L. (2000). Strategic Management in Tourism, CABI Publishing, New York.

Page, S. J. (2015). Tourism Management, 5th ed., Routledge, London.

Perulli, P. (2015). Un’Agenda per Milano Globale. Imprese \&Città, Rivista Della Camera Di Commercio Di Milano, 6.

Pine, B. J. \& Gilmore, J. H. (1999). The Experience Economy: Work is Theater and Every Business a Stage, Harvard Business School Press, Boston.

Ponzini, D., \& Nastasi, M. (2011). Starchitecture: Scenes, Actors and Spectacles in Contemporary Cities, Umberto Allemandi \& C., Turin.

Porter, M. E. (1995). The Competitive Advantage in the Inner City, Harvard Business Review, May/June, 55-71.

Power, D. \& Hauge, A. (2008). No Man's Brand - Brands, Institutions, Fashion and the Economy, Growth and Change, 39, 123-143. 
Power, D.. \& Scott, A. (2004). A Prelude to Cultural Industries and the Production of Culture, in Power, D. and Scott, A. (eds.), Cultural Industries and the Production of Culture, 3-15, Routledge, London.

Richards, G. \& Raymond, C. (2000). Creative Tourism, ATLAS News, 23, 16-20.

Richards, G. (ed.). (2001). Cultural Attractions and European Tourism, CABI, Wallingford.

Salvioni, D. M. \& Astori, R. (2013). Sustainable Development and Global Responsibility in Corporate Governance, Symphonya. Emerging Issues in Management (symphonya.unimib.it), (1), 28-52.

http://dx.doi.org/10.4468/2013.1.03salvioni.astori

Sassen, S. (1991). The Global City, Princeton University Press, Princeton.

Scott, A. J. (2000). The Cultural Economy of Cities: Essays on the Geography of Image-Producing Industries, Sage, London.

Symbola (2016). Rapporto 2016 Io Sono Cultura. Retrieved in http://www.symbola.net/html/article/Rapporto2016IOSONOCULTURA

Sweeting, D. (2002). Leadership in Urban Governance: The Mayor of London, Local Government Studies, 28, 3-20.

Throsby, D. (2001). Economics and Culture, Cambridge University Press, Cambridge.

Vanhove, N. (1996). Globalisation of Tourism Demand: The Underlying Factors and the Impact on Marketing Strategy, in Keller, P. (ed.), Globalisation and Tourism, AIEST, St. Gallen.

Volo, S. (2009). Conceptualizing Experience: A Tourist Based Approach, Journal of Hospitality Marketing \& Management, 18(2-3), 111-126.

http://dx.doi.org/10.1080/19368620802590134

Weller, S. (2007). Fashion as Viscous Knowledge: Fashion's Role in Shaping Trans-National Garment Production, Journal of Economic Geography, 7, 39-66.

World Economic Forum. (2015). The Travel and Tourism Competitiveness Report 2015. Retrieved in http://www3.weforum.org/docs/TT15/WEF_Global_Travel\&Tourism_Report_2015.pdf

Yeung, H.W.C. (2005). The Firm as Social Networks: an Organisational Perspective, Growth and Change, 36(3).

Zukin, S. (1995). The Cultures of Cities, Blackwell, Oxford. 